\title{
Padma or No Padma: Audience in the Adaptations of Midnight's Children
}

The Journal of Commonwealth Literature 2017, Vol. 52(3) 50I-5I8 (C) The Author(s) 2016

Reprints and permissions: sagepub.co.uk/journalsPermissions.nav DOI: $10.1177 / 002198941667 \mid 171$ journals.sagepub.com/home/jcl

(\$SAGE

\author{
Ana Cristina Mendes
}

Universidade de Lisboa, Portugal

\section{Joel Kuortti}

University of Turku, Finland

\begin{abstract}
It is remarkable that what many consider as Salman Rushdie's landmark work in fiction, Midnight's Children, was first adapted to film only in 2012, 31 years after its publication. It was also the first of his works to be filmed. This is noteworthy given the novel's cinematic self-awareness and the writer's overt interest in acting and cinema, which he has reiterated over the years. Cinema, as a subject matter and a distinctive artistic language, resurfaces time and again in the pages of Rushdie's essays, short stories, novels, and other writings. As many critics have pointed out, the writer's emotional connection to cinema has translated into cinema itself being put to work as a mediating device in his oeuvre, with his characters often making sense of themselves and the world - and coming to terms with their own place in it - through cinema. In this article, we examine the three existing adaptations of Midnight's Children, with particular emphasis on the 2012 film, in view of their discursively constructed audiences. We consider these adaptations from the point of view of the audience, and how they engage with the spectator/reader. Our analysis is supplemented by Rushdie's essays on the acts of adaptation and translation from one artistic medium to another. Our purpose is not to measure the failure or success of Rushdie's and Mehta's adaptation (although an aesthetic evaluation would indeed be of interest); we argue instead that the film adaptation is a protracted creative project that has taken into consideration, more than previous adaptations of the novel, not only new forms of representation and new ways of reading, but also new ways of engaging its constructed audiences.
\end{abstract}

\section{Keywords}

adaptation, audience, cinema, Midnight's Children, Salman Rushdie, screenplay

\section{Corresponding author:}

Ana Cristina Mendes, Alameda da Universidade, Universidade de Lisboa, Faculdade de Letras, Lisboa, 1600-

214, Portugal.

Email: anafmendes@gmail.com 


\section{Introduction: Author, audience, and adaptation}

It is remarkable that what many consider as Salman Rushdie's landmark work in fiction, Midnight's Children (1981; MC), was first adapted to film only in 2012, 31 years after its publication. It was also the first of his works to be filmed. This is noteworthy given the novel's cinematic self-awareness ${ }^{1}$ and the writer's overt interest in acting and cinema, which he has reiterated over the years. ${ }^{2}$ Besides publishing, Rushdie has had a long career in the creative economy - in the 1960s as a television scriptwriter in Karachi after acting in the Cambridge Footlights Revue; in the 1970s as a freelance copywriter in advertising agencies and as an actor on the London fringe; and in later years as a scriptwriter and performer of cameo roles in films. Cinema, as a subject matter and a distinctive artistic language, resurfaces time and again in the pages of Rushdie's essays, short stories, novels, and other writings. As many critics have pointed out, the writer's emotional connection to cinema has translated into cinema itself being put to work as a mediating device in his oeuvre, with his characters often making sense of themselves and the world — and coming to terms with their own place in it — through cinema.

Studies focusing on Rushdie's use of cinematic tropes and, at the narratological level, on his novels as cinematic narratives per se, can be traced back to Nicholas D. Rombes's 1993 essay on The Satanic Verses (1988), which highlights the writer's "prevalent use of 'film-language' to describe various scenes" and his adoption of "various cinematic strategies not only to create 'visual' images (frequent aerial or high shots, for instance) but also to shape the narrative [...] (focus-through or racking, dissolves, and cross-cutting, for instance)" (Rombes, 1993: 47). ${ }^{3}$ Not only are cinematic techniques and features built into his narratives, but diverse filmic intertexts are also mobilized in his fictional works ${ }^{4}$ to create a strong sense of the constructedness and fluidity of identity, and the multiple and overlapping layers which constitute identity.

Midnight's Children has been adapted three times so far, first for television (MCS) in 1998 by Rushdie, then for theatre (MCT) in 2002, again by Rushdie with dramaturg Simon Reade and director Tim Supple, ${ }^{5}$ and lastly for film $(M C F)$ in $2012 .{ }^{6}$ Both of the earlier adaptations have also been published as books: The Screenplay of Midnight's Children (Rushdie, 1999b), and Salman Rushdie's Midnight's Children: Adapted for the Theatre (Rushdie, Reade, and Supple, 2002). The film screenplay, the most recent of these, was written by Rushdie and the Indian-Canadian director Deepa Mehta; in the film Rushdie also appears as the narratorial voiceover, and Satya Bhabha (who plays Saleem) is the son of Rushdie's friend, the postcolonial theorist Homi K. Bhabha.

In this article, we examine the three existing adaptations of Midnight's Children, with particular emphasis on the 2012 film, in view of their discursively constructed audiences. ${ }^{7}$ In the following, we consider these adaptations from the perspective of the audience, and evaluate how they engage with the spectator/reader. Audiences are large and diverse. By "audience" here, we do not mean any specific (reader or spectator constituent) or intended (target) audience, but rather an audience that is constructed discursively through various ways of address, such as via film trailers. Our analysis is supplemented by Rushdie's essays on the acts of adaptation and translation from one artistic medium to another. ${ }^{8}$ Our purpose is accordingly not to measure the failure or success of Rushdie's and Mehta's adaptation (although an aesthetic evaluation would indeed be of interest); we argue instead 
that the film adaptation is a protracted creative project that has taken into consideration, more than previous adaptations of the novel, not only new forms of representation and new ways of reading, but also new ways of engaging its constructed audiences. Comparisons with the novel are not made in order to calibrate its success but as variations on a theme with two foci: the question of beginning, and the question of address. We conclude that the adaptation by the author of the "original" presents different types of adjustment, and that the questions of audience and media are more relevant.

As with the 2012 film adaptation, Rushdie was involved in the other adaptations as both author of the source text and screenplay writer and co-adaptor, thus "authorizing" these dramatizations. This direct involvement prompts such questions as: What is at stake when the author of the "source" text participates in the adaptation, co-creates it, and thus wishes to retain prolonged authorial control over the text? What implications do the merging of author and voiceover narrator have for the reception? What is involved when the author breaks "the fourth wall", speaking directly to the audience through the imaginary barrier that, by convention, separates viewers from the characters (and the author)? What happens when the typically central issues in adaptation theory (authorship, authenticity, fidelity, and intertextuality) become marginal? To offer tentative answers to these questions here, we will first consider critical considerations and Rushdie's own views on adaptation, before analysing the adaptations especially through audience construction.

\section{The unbearable lightness of adaptation: Rushdie on adaptation}

In Rushdie's novel Shame, the authorial narrator makes an often-quoted comment on translation: "It is normally supposed that something always gets lost in translation; I cling, obstinately, to the notion that something can also be gained" (1983: 29). This could well be a way to regard the unbearable lightness of literature-to-film adaptations, ${ }^{9}$ not as poor second cousins transposed into a second rate medium — in Midnight's Children, Hanif's mother considers "the cinema to be an extension of the brothel business" (59) — but as a kind of textual migration with its own, independent merits. ${ }^{10}$

The ideas of fidelity and equivalence (correspondingly appearing in translation studies) have been common and persistent in adaptation studies, ${ }^{11}$ and bring forth more general issues of intertextuality, authorship, copyright, appropriation, plagiarism, and citation. ${ }^{12}$ The (assumed) replicative and (factual) collaborative nature of cinema supplements these issues, which is amply illustrated by the extent of the credits of any given film. Lucy Fischer formulates the question as follows: "what constitutes a cinematic signature or creative marker: does it reside within the script $[\ldots]$ or in the mise-en-scène [...]?" (2013: 7). While it is not within the scope of this article to resolve this question, in the following sections we address the borderline between the "original" and the "copy", especially through the examination of the discursive construction of the audience.

Rushdie's broad definition of adaptation in the more recent article "A Fine Pickle", published in The Guardian, encompasses "translation, migration and metamorphosis, all the means by which one thing becomes another" (2009: n.p.). For him, examples of 
"successful" adaptations include Martin Scorsese's The Age of Innocence (based on Edith Wharton's 1920 novel of the same name), Luchino Visconti's The Leopard (based on Giuseppe di Lampedusa's 1958 work Il Gattopardo), John Huston's Wise Blood (based on Flannery O'Connor's 1952 book), and David Lean's Great Expectations (based on Charles Dickens' 1861 novel). With customary boldness, Rushdie considers Peter Jackson's Lord of the Rings trilogy to be superior, as a work of art, to Tolkien's novels, because "Jackson makes films better than Tolkien writes" (2009: n.p.).

Literature is fundamentally a negotiation between media. This is probably one of the reasons why, since the inception of cinema as a new art form, it has been so permeable and amenable to film adaptation. There are, besides Midnight's Children, at least four highprofile adaptations with a release date of 2012 - Cloud Atlas, Silver Linings Playbook, Beasts of the Southern Wild, and Life of Pi. ${ }^{13}$ This close relationship between literature and film, as perhaps in all such cross-media relationships, has had its skirmishes alongside moments of stimulus and interdependence. Consequently, the question of adaptation has a long history in film studies following on from George Bluestone's Novels into Film (1957), and the process has recently been theorized in terms of, for example, "translation, performance, dialogue, recycling, ventriloquizing, or decomposing" (Fischer, 2013: 7). ${ }^{14}$ Robert Stam (2012-13) writes of a well-stocked archive of tropes and concepts to account for the mutation of forms across media - adaptation as reading, rewriting, critique, translation, transmutation, recreation, transvocalization, transfiguration, actualization, performance, transmodalization, dialogization, cannibalization, revoicing, and reaccuentuation. The new media, meanwhile, have generated innovative metaphors, whereby adaptation can be seen as a "transcoding" or "reformatting" of the novel. Each term sheds light on a different facet of adaptation. The metaphor of translation, similarly, "suggests a principled effort of intersemiotic transposition, with the inevitable losses and gains typical of any translation" (Stam, 2012-13: 180).

Adaptation studies have long destabilized the act of privileging the written text over its filmic adaptation, urging viewers and critics alike to regard adaptations as new texts in conversation with "source" texts. Jack Boozer, arguing against the binary between the literary source text and the screenplay, sees literature-to-film adaptation as a collaborative process that

involves the textual transposition of a single-track medium of published writing into a document that embraces the scenic structure and dramatic codes of the multitrack medium of film. The composition of the screenplay illuminates the evolution of ideas that will determine the film production's relationship to its source text. (Boozer, 2008: 1)

This is a concise definition, and the dividing line is further demarcated by copyright laws and film industry practices, such as the Academy Awards at which there are separate categories for original and adapted screenplays (Boozer, 2008: 13-14). ${ }^{15}$ One way of bypassing the cul-de-sac of essentializing value judgements suggested by Thomas Leitch in Film Adaptation and Its Discontents (2007) - with its Freudian allusion — is a pedagogical one, a move towards the Barthesian writerly text: active literacy in which "source texts must be rewritten" (Leitch, 2008: 16). The "original" is not a touchstone against which the "copy" is measured, but material to be worked with. 
In a rather uncharacteristically despondent take on film adaptation in his introduction to the Midnight's Children television screenplay, Rushdie (1999a: 2) notes, "Books and movies are different languages, and attempts at translation often fail". Elsewhere, in a 2011 interview, he states that "TV drama is the new literature" - a position more aligned with his constant undermining of the notion that the label of cultural prestige can only be attached to the printed page (Bingham, 2011: n.p.). ${ }^{16}$ Finally, in "A Fine Pickle", Rushdie writes: "Everyone accepts that stories and films are different things, and that the source material must be modified, even radically modified, to be effective in the new medium. The only interesting questions are 'how?' and 'how much?"' (2009: n.p.). As a way to respond to these questions and tease out the problematics involved in the above assertions, in the following five-part section we look in detail at the four extant versions of Midnight's Children, namely the novel and its three adaptations.

\section{Variations on a theme: An analysis of three adaptations}

\section{I: Three adaptations}

Rushdie steered the project of adapting Midnight's Children into film from the outset, exercising an even tighter creative control than in the earlier adaptations, co-authoring the script and acting as executive producer. Rushdie wanted Mehta to direct the film to the extent that — as he declared in an interview — he sold her the rights to the novel for the nominal fee of US \$1 (Canfield, 2013: n.p.). Another instance of this greater creative control is the use of his own voice to narrate the film, although the choice itself is attributed to Mehta's insistence (Wallace-Wells, 2013: n.p.).

The earlier attempt at making a television production based on the 1981 novel failed in 1998, when the BBC abandoned the production of a five-episode television dramatization, a project involving "two writers, three directors, at least four producers and a whole passionately dedicated production team" (Rushdie, 1999a: 1). This happened after the Indian government denied permission to film, and attempts to relocate the project to Sri Lanka nosedived due to pressure from the Muslim community (Rushdie, 1999a: 11). Rushdie recounts this ordeal in his memoir Joseph Anton (2012: 524-6), as well as in the introduction to the 1999 screenplay. The "story of a production that never was" is fully documented in this introduction - its ending is related thus: "Like Sisyphus, we had to watch the undoing of all our work, as the great rock of our production ran downhill into a Sri Lankan ditch" (Rushdie, 1999a: 11). Rushdie (1999a: 12) concludes the introduction with a prediction that "a film brought into half-being by the publication of its screenplay may yet manage, someday, to get itself born". In the optimistic postscript that follows the essay's republished version in Step Across This Line, Rushdie (2002: 79) writes about the upcoming theatrical adaptation and of there being "once again much interest in turning Midnight's Children into a feature film".

The Royal Shakespeare Company (Barbican) put on stage a three-hour-15-minutelong theatrical adaptation - drawing on the television version - that premiered in January 2003 with a 20-strong cast. A mixed-media approach, comprising historic newsreel, shadow-play, and specially shot episodes, was adopted to enhance the theatrical production. Notwithstanding these adaptive efforts, the critics seemed, for the most part, to adhere tightly to the primacy of the literary original. The Guardian theatre critic 
Michael Billington rated it three stars, commenting: "Adapting Salman Rushdie's epic novel for the stage is like trying to lasso a leviathan" (2003: n.p.). Another critic, Philip Fisher (2003: n.p.), was more appreciative, but also found it a poor second to the novel: "This is a great production, richly symbolic and a wonderful achievement [...] but it is no replacement for the incomparable richness of the real thing. Go and see it but read the book too".

The prophecy verbalized in Rushdie's 2002 postscript would only come to be realized a decade later, when Rushdie and Mehta decided to collaborate on a film adaptation. Again, the British-Canadian project was fraught with socio-political challenges. To circumvent opposition in both India and Pakistan, the 140-minute film was shot mainly in Sri Lanka under the title Winds of Change, with additional shoots in Kashmir (Dal Lake), Agra (Taj Mahal), Mumbai, and Karachi (Cox, 2013: n.p.). Inviting comparisons with Midnight's Children's protagonist Saleem Sinai, it took the film more than 30 years to be born.

\section{II: Trailers constructing audiences}

Scrutiny of the three different trailers (from Canada, the UK, and the US) ${ }^{17}$ of Mehta's (2012) Midnight's Children provides initial insights for audience analysis, as trailers in general rely on unique, audience-specific selling points. Trailers provide an important instrument for assessing the possible target audiences as they contextualize the film in a specific manner for marketing purposes, in ways that may differ from the film itself. As marketing tools, they are obviously tailored for and targeted to intended audiences. Rushdie alone is the strongest selling point, but he is featured differently throughout these trailers. In an interview with the author, David Wallace-Wells comments: "There are not many literary novelists who could deliver a publicity boost to an epic movie spectacular, or whose voice might be helpfully recognizable to moviegoers not just here but in India, Canada, and England" (2013: n.p.). Wallace-Wells continues to say that Rushdie is such a figure, but this is a mixed blessing as

it's likely that, despite what Rushdie says about being reluctant to include narration ("The script that we shot had no voice-over at all"); and about Mehta having to insist that he perform it himself ("What Deepa wants, Deepa gets"); despite all that, it's likely that Rushdie's voice-ofGod role in the film will be seen as a flourish of authorial vanity. (Wallace-Wells, 2013: n.p.)

Rushdie's (perceived) personality traits have often been referred to in the criticism of his works and life in general (see Valovirta and Kuortti, forthcoming; Mendes, 2013). Even if Mehta took a secondary role to Rushdie during the promotion of the film, judging from the available material, it might be far-fetched to consider the voiceover as a manifestation of "authorial vanity". The author-audience bond is built and reinforced through the voiceover, but even then it remains contestable, which is also reflected in the trailers.

Whereas the UK and the US trailers stress that the film was adapted and narrated by Rushdie himself, the Canadian one makes no explicit reference to him as narrator, only to his status as acclaimed author, and chooses to draw attention instead to the fact that this is a film by Mehta, the "director of the Academy Nominated film Water". Though the 
UK trailer also acknowledges that the film is directed by the "Academy Award Nominee", the Canadian trailer chooses to give stronger emphasis to Mehta's role, arguably to prompt a feeling of national pride. A way to gauge these different perspectives is to consider the use of Rushdie as selling point. Moreover, these options arguably speak to the different ways in which Rushdie is perceived in these countries; one could speculate, too, that this may be one of the reasons why the Canadian version overlooks Rushdie's voiceover. $^{18}$

Creating trailers for different nationally-constituted audiences (however diverse nationality-wise) involves multiple acts of translation across cultures. Rushdie seems to adopt the role of the translating narrator, with the narration occasionally breaking into moments where the ostensibly seamless translation reveals its fault lines. The UK trailer opens with Jawaharlal Nehru's "midnight tryst with destiny" speech celebrating India's independence from British rule. In its chain of cultural signification, opening with Nehru's speech clearly plays with the specificities of the British experiences of imperial nostalgia and convivial living that Paul Gilroy discussed over a decade ago.

In fact, reverberations of what Gilroy (2004) dubbed "postcolonial melancholia" might still be discernible in the not-so-postcolonial (here, we are drawing on the temporal and periodizing associations of the term) Britain of the 2010s, where the first episode of the Channel 4 drama series Indian Summers aired on 15 February 2015, and was watched by 4.82 million, according to the Broadcasters' Audience Research Board (2015). ${ }^{19}$ Like previous Raj narratives (such as the television series The Jewel in the Crown and The Far Pavilions, both in 1984, and the films Conduct Unbecoming [1975] and A Passage to India [1984]), Indian Summers is set in British colonial India (in 1932, in the second season in 1935) and brings forth nostalgic echoes of the Empire that Rushdie (1984b) labelled Empire-revival, Raj-revival, and even Raj-revisionism. ${ }^{20}$

Given the perceived specificities of the intended audiences' experiences, it seems logical to have the film marketed in the Canadian trailer as an adaptation "from the beloved novel" and in the US version from the "internationally acclaimed novel", while the UK trailer sells it as an adaptation "from the 'Best of Booker' prize-winning novel", and draws attention to the original music score by the British Asian musician Nitin Sawhney. After all, such captions identify possible points of rendezvous between the expected audience and the story and/or its author.

The US trailer adopts an exoticizing stance, depicting the 1947 Independence Day as a spectacle on display, offering footage of Nehru's Independence speech interspaced with shots of fireworks and celebrations in the street. This trailer has acoustic Indian music at the beginning to give the audience a tangible context. In fact, the music follows the basic dramatic arc of trailers by showing us the characters, focusing on the protagonist Saleem, the obstacles the new nation and he are facing, and their handcuffed development that unfolds between the beginning of the film and its end. The tempo of the music increases with a Western orchestral string-based theme, punctuated by distant drums, as the "mysteriously handcuffed" political and personal narratives become unsettled by the martial law of Emergency. This is followed by a caesura where Saleem is menaced by his "midnight twin" Shiva, who threatens that he will take Saleem's life away, in vengeance for his own having been taken by being switched at birth. After this 
break, a dramatic choral theme further facilitates an emotional connection to the protagonist, now at a turning point, and paves the way for the reflective aftermath.

As signs of validation, while the UK trailer highlights the film's screening at prestigious venues such as the London, Toronto, and Telluride film festivals, as well as a blurb by Rushdie himself stating "I am very proud of this film", the US trailer presents, in title slides, excerpts of reviews from The Times of India, The Chicago Tribune, and Variety. Rushdie's voiceover is used throughout the three trailers, adding validation and once again making it easier for the viewer to grow connected to the narrative.

\section{III: Once upon a time: Beginnings (and ends)}

To continue our analysis of audience, we will consider the beginnings of Midnight's Children and its three existing adaptations. In general, beginnings are important for the attention of the audience, whether spectators or readers, so this seems a natural choice; it is all the more so, as the difficulty of beginning a story is one of the quandaries of the novel (Phillips, 1989: 202). This structural issue of representing the extended problematics of beginning - what Rushdie describes in The Satanic Verses as "how newness enters the world" (Rushdie, 1991: 394) — is managed in different ways in the versions under scrutiny. However, this will not, as such, be discussed here, since we instead concentrate on beginnings proper: how the different versions actually begin.

In contrast to the beginnings, the endings offer little variation. In fact, all other versions except the film end with the same words: "Because it is the privilege and the curse of midnight's children to be both masters and victims of their times, to forsake privacy and be sucked into the annihilating whirlpool of the multitudes, and to be unable to live or die in peace" (MC: 533; MCS: 308; MCT: 119). The contextual circumstances vary somewhat, but the bleakness of the future looms in all texts except for the film, where the end points out that — "in spite of everything" — there is still hope in the narrative:

A child and a country were born at midnight. Once upon a time. Great things were expected of us both. The truth has been less glorious than the dream. But we have survived and made our way. And our lives have been, in spite of everything, acts of love. [Fireworks] (MCF: $136 \mathrm{~min}$.)

The authorial licence is here used to uplift, while serving the need for resolution in a film intended for popular spectatorship.

The film begins in a festive mood, with music, dancing, and fireworks. The voiceover of the narrator Saleem, performed by Rushdie, recounts the coinciding events of his birth and that of independent India (and, although not explicated, Pakistan following the partition of British India). This concurrence, described in terms of being "mysteriously handcuffed to history", is also present in the novel's opening, where Saleem tells the same story, also in the first person $(M C: 3)$. The form of direct address is used in all three adaptations.

The film and the novel start in a similar way — "I was born in the city of Bombay ... once upon a time" - and the differences are in the material provided in the textual or graphic details. In the novel, the immediate circumstances of Saleem's birth are described (Doctor Narlikar's Nursing Home, his father breaking his toe), while in the film, the 
music, dancing, and fireworks - although generic and not specified - suggest something grander than the prosaic birth of a boy. The move to the next scene in Kashmir in 1917 takes place under the guidance of the narrator, who says that "my life really began on the shore of the Dal Lake in Kashmir" (MCF: 1:04 min.). The landscape across the lake (shot on site) emphasizes the serenity and timelessness of the place as the fit-looking boatman Tai - not the leathery, ageless, toothless old man of the novel — presents the prophecy of Aadam Aziz's nose.

At this point, a significant choice in terms of language has been made in the film adaptation. The original English text has, in places, been replaced with Urdu or Hindi to reflect the factual linguistic situation in any given scene. The character of the boatman Tai would not have had command of English, and the code-switching between - and the hybrid usage of - English and Indian vernacular languages contributes to social realism. The novel promotes instead the "chutnification" of English in order for the language to be "remade in other images" (Rushdie, 1982: 8). Several kinds of Indo-English linguistic practices - word order, syntax, lexis, compounds, and so on - as well as codeswitching, hybrid linguistic forms, and idiosyncrasies, are employed to achieve the effect of linguistic social realism, whatever the level of intentionality may be. ${ }^{21}$ The chosen strategy for the film certainly makes a difference as, depending on one's proficiency in Urdu or Hindi, the experience is dissimilar.

Even though they are in many other ways closer to each other than to the novel or the film, the television and theatre scripts have distinctive beginnings, as we can see in the following passages.

The television script:

\section{EXT. FAIRGOUND. DAY}

A huge CROWD of people at a fairground. The infinite CROWD that is India. We single out a man, LIFAFA DAS, with a peep-show machine on wheels, rattling an old and battered dugdugee drum.

Lifafa Das Dilli-dekho dilli-dekho dilli-dekho! Come see Delhi come see Bombay come see!

Come see come see come see! (MCS: 15)

And the theatre script:

A film screen dominates the stage and shows us the infinite crowd that is India today - a present-day, carnivalesque Independence Day celebration which bleeds into other aspects of modern India, the potent contrasts and diversity of religious and secular, urban and rural, north and south. This montage is accompanied by music.

Tick, tock ...

We then start to hear Jawaharlal Nehru begin his "Tryst With Destiny" speech, while the noise of the crowds grows, as Independence looms at midnight, 14/15 August 1947. 
Simultaneously on stage we see two birth scenes in the Narlikar Nursing Home - a nice white linen-made bed with plenty of towels, alongside a basic metal bed. (MCT:1)

Both versions commence with a crowd; however, in the television script Lifafa Das has been given the theatrical function of introducing the five episodes, whereas in the theatre script a film screen performs this function. In the novel, Lifafa Das's function is to lead Saleem's mother Amina to Shri Ramram Seth for divination of her child, while in $M C T$ he is more a kind of vidūshaka, a buffoon character and a commentator on events in Sanskrit drama and Indian folk theatre (Varadpande, 1992: 9). In the TV script Lifafa Das's peep show machine is employed as an entry to a series of photographs that are not specified but which his shout-outs name as Love in Kashmir and Independence (MCS: 15), Connaught Place, and Qutb Minar (71), the Taj Mahal and Mount Everest (72), land from water (111), pepperpot soldiers (163), haunted jungle (211), and hostile Widow (263). At these particular points, the narrative progression relies on these announcements, as Saleem's comment to Padma confirms: "Everything followed from him" (71). This reading is matched with Rushdie's (1999a: 7) comment that, in writing the screenplay, he was "much less respectful of the original text than Ken had been", 22 and one of the new elements was Lifafa Das's role.

If it is noticeable that the television screenplay uses theatrical methods, it is equally remarkable how the theatre production utilizes filmic techniques through newsreel footage from the General Assembly. This is certainly a very effective and economic way of encapsulating a layered narrative onstage. At the same time, however, it presents the events as a documentary-style representation of Indian history, opening a historicalrealist horizon of expectation. In the other versions, the documented speech comes much later - 125 pages in $M C, 88$ pages in $M C S$ and 30 minutes in $M C F$ - when the narration has again reached the double moment of birth and independence.

\section{IV: Padma: The question of address}

In the opening scenes we can observe differences in the way the versions address the audience: the novel's narrator uses the first person to provide, in a deferred and roundabout way, his story; in the film, there is also direct speech, but the narrative proceeds much more unswervingly. The other two versions do not construct a rapport with the audience in such a straightforward way by direct address. In $M C S$, it is Lifafa Das who calls out the invitation to see the events, followed with the prophecy of Saleem's birth. In $M C T$, the audience is shown both the historical background on screen and the event of the twin births on stage. Only after these opening scenes does the narrator step in, either as a voiceover (MCS: 16) or as a character onstage (MCT:2).

The novel and the film thus seem to initially create a more personal rapport with their constructed audiences. It is significant in this respect that the character of Padma, the novel's original immediate addressee and audience — the person who listens to and comments on Saleem's narrative, and the second main character in the novel, after the protagonist - is included in the first two adaptations, but in the film she is supplanted by Rushdie's voiceover. Padma's role in the film was originally offered to the actor Nandita Das, who had worked with Mehta in Fire and Earth, but Das abandoned the project for 
personal reasons (Garfinkel, 2009; IBNLive, 2011). Rather than looking for a substitute for the role of Padma, this setback was compensated by introducing the voiceover. The choice has been regarded variously as a success and a failure by critics, for example, from the gender perspective. There are indeed grounds for interpreting the substitution of a female voice with a male as problematic; this change may even be attributed to the authorial ego. However that may be, it creates a fundamental difference between the versions.

In the novel, it is only in the second chapter that Padma appears and is established as the constructed audience. In $M C S$ and $M C T$, Padma appears quite early in the narrative — after Saleem has introduced himself and his birth — in her role of a caregiver: "Eat, na. Food is spoiling. At least try some green chutney. Your favourite" (MCS: 18; MCT: 3). Padma, as an eager listener, takes on a role through which she persuades Saleem, often less subtly via "the Padma-pressures of what-happened-nextism" (MC: 39), to get on with his story. The suspended mode follows Laurence Sterne's narration in Tristram Shandy (1759-67), and similarly Saleem in the novel is apologetic for the deferral, addressing the audience: "But here is Padma at my elbow, bullying me back into the world of linear narrative, the universe of what-happened-next" $(M C: 38)$.

Discussing the suspense element in the novel, Nancy E. Batty (1987: 53) observes that Padma "plays an important role in the creation of [Saleem's] story". Batty (1987: 57) compares "Saleem's technique to that employed by episodic cinema", which is that of focalization, given the cinematic self-awareness of the novel. The story evolves as a dramatized duel between the narrator and the audience, between Saleem and Padma ("At this rate", Padma complains, "you'll be two hundred years old before you manage to tell about your birth"; $M C: 38)$.

One further role Batty (1987: 57) attributes to Padma is that of "an index for readerresponse to the framed narrative", someone who interprets and estimates for the reader and/or spectator the level of credibility of the story. Uma Parameswaran (1983: 44) argues against the perception of Padma as a vidushika (meaning vidūshaka or clown), and suggests instead of comedy a dramatic role, that "Padma is like the chorus in a Greek drama - always on the stage, but never initiating action". Batty likewise considers the clown too passive a role (1987: 54), and Padma's function is, indeed, significant as Saleem continuously veers away from perceived factuality in the sequence or detail of events (see MC: 510; Rushdie, 1984a; Stephens, 1985). We argue that Padma resembles more closely the sütra-dhāra - puller of strings — of Indian classical Sanskrit ("Theatre", 2015) and folk theatre (Varadpande, 1992: 12). Even when absent "Padma would believe me; but there is no Padma" (MC: 170) — Padma is the driving force for Saleem: "This is what keeps me going: I hold on to Padma. Padma is what matters" (MC: 337).

\section{V: No Padma: The author-audience bond}

What happens, then, when there is no Padma, as in the film? How does the narrative proceed when she is not there to probe Saleem to get on with the story - "You better get a move on or you'll die before you get yourself born" $(M C: 37)$ - or to question the validity of his claims — "All the time [...] you tricked me" (MC: 131)? To begin with, 
Padma's questioning (and doubting) voice disappears. In the 39 instances wherein the film's narrator appears, only four present questions, while the remaining are declarative statements. In three of these, the questions are immediately answered by the narrator: "Why did she marry him so quickly? For solace? For the children they both wanted so much? My mother, Ameena Sinai, in her new incarnation resolved to forget the poet Nadir and fall in love with my father, Ahmed Sinai" (MCF: $24+$ min.); "Only exile? In exile, I learned about power" (MCF: 70+ min.); "Who were we? We were the promises of Independence" (MCF: 115+ min.). The single question that is not answered comes towards the end: "And what of Shiva, Shiva who was now a wanted man?" (MCF: 115+ min.). This is also one of the two main differences (including the absence of Padma) between the film and the novel: in the novel, what happened to Shiva is left uncertain — "To tell the truth, I lied about Shiva's death. My first out-and-out lie [...] I'm still terrified of him" - $(M C: 510)$, but in the film he rides into a truck and dies, which is implicit only inasmuch as his body is not shown. One may speculate that the significance of this change resides in the fact that the film is less open to interpretation and, together with the slightly more optimistic ending discussed earlier, turns the gaze from oppressive past to future.

With respect to the impact on reception of having the author in Padma's role, the use of Rushdie's voice for the narration has received mixed reviews. One reviewer notes how the voiceover technique "makes it feel like Rushdie is sitting next to you in the audience, nudging you in the ribs, over-explaining the story and still expecting you to laugh and cry at the right moments" (Ahmed, 2013: n.p.). Another one finds the choice more pleasing: "It's a masterstroke having Rushdie provide the film's narration. His instantly-recognisable tone reciting his self-penned words render him a comforting guide on this tumultuous journey" (Joshi, 2012: n.p.).

The fact that the voiceover conflates the moment Saleem came from his mother's womb and the actual historical event of India's independence takes the audience to a metafictional level if they realize (or know in advance) that the actual person narrating the story was also born around the time of India's independence, on 19 June 1947, only two months before the cataclysmic subcontinental events of August $1947 .{ }^{23}$ In this sense, the film can be interpreted as a semi-autobiographical narrative, one which is adapted by Rushdie himself from his own novel and roughly based on his childhood - facts that are emphasized in the movie's trailers.

\section{Conclusion: How? And how much?}

If we accept, as Rushdie contends, "that stories and films are different things, and that the source material must be modified, even radically modified, to be effective in the new medium" (2009: n.p.), it leaves space to consider the ways in which adaptations demarcate themselves from the "source" text in a concrete rather than evaluative way. In this article, we examined what happens when the author of the "source" text is involved in the adaptation. We have demonstrated how the merging of authorial position and voiceover narrator creates a new platform of address, which may be used, for example, as a promotional lever (as in the Canadian and UK trailers). Without intending to assume definite claims as to its success (although partial testimonies can be drawn upon), the (radical) transformation of the address indicates another kind of understanding of the 
audience(s). In the case of the adaptations of Midnight's Children, Rushdie's authorial position has enabled productions (even if they failed, as in the case of $M C S$ ) that, at the same time, both diverge from the original and retain fidelity. With its particular differences in relation to the other versions, the 2012 film constructs its audiences in cinematic terms. Padma-less, it relies on a rapport with its constructed audience and in return offers a new, slightly less bleak reading of the fate of India's midnight's children.

\section{Declaration of Conflicting Interests}

The author(s) declared no potential conflicts of interest with respect to the research, authorship, and/or publication of this article.

\section{Funding}

The author(s) received no financial support for the research, authorship, and/or publication of this article.

\section{Notes}

1. For example, Nalini Natarajan demonstrates "the symbiotic connection between Midnight's Children and Bombay cinema" (1999/1994: 400).

2. In an interview with New York Magazine to promote the film, Rushdie confesses: "I really wanted to be an actor [...]. It was the other thing I wanted to be. What's difficult for me to work out is that, given that I was very involved in theater, and given that I was very obsessed with movies, I ended up doing this thing that you do by sitting alone in a room" (WallaceWells, 2013: n.p.).

3. The visual strand of analysis would most likely have been stronger earlier in Rushdie studies without the intervening affair of The Satanic Verses, which redirected criticism to other issues. An early example of this strand is Deborah Bowen's $\mathrm{PhD}$ dissertation on photography and literature, Mimesis, Magic, Manipulation: A Study of the Photograph in Contemporary British and Canadian Novels, where it is argued that Rushdie's use of photography "parodies a traditional understanding of mimesis" (1990: 322). Later, Ana Cristina Mendes' (2012) edited collection brought together research on the visuality of Rushdie's work, and scholars such as Vijay Mishra (2012) and Florian Stadtler (2013) have further explored the theme. Stadtler devotes a chapter of his Fiction, Film and Indian Popular Cinema: Salman Rushdie's Novels and the Cinematic Imagination to commenting on Rushdie's own critical writing on film and addressing screenplays of his fiction, with particular emphasis on the three adaptations of Midnight's Children. Though we are here using the same corpus, our angle of analysis is different, as Stadtler focuses on Rushdie's relationship with, on the one hand, Indian popular cinema and, on the other, art house and commercial cinema from across the world.

4. For example, the Western cinematic intertext is extensive in The Satanic Verses (1988; page numbers are cited from the 1989 edition): the "great D. W. Rama", an Indian film director whom the character Gibreel works for, echoes the name of the Hollywood filmmaker D. W. Griffith (11); Alphaville, one of London's aliases at the beginning of the novel, brings to mind the dystopian metropolis of Jean-Luc Godard's 1965 film of the same name (4); "a pair of green-tinged spectacles" (22), a "yellowbrick lane" (282), and "four hundred and eighty-one pairs of ruby slippers" (361) take us to the world of Oz; Greta Garbo and Grace Kelly ("Gracekali") are described as "goddesses from heaven" (25); the title of David Lean's Brief Encounter (1945) is alluded to when Gibreel thinks about his frustrated love affair with the character Alleluia Cone (31); there are incidental references to Love Story (dir. Arthur Hiller, 1970) (64), The Magnificent Seven (dir. John Sturges, 1960) (a western film which is a 
remake of Akira Kurosawa's 1954 film Seven Samurai) (64), Blade Runner (dir. Ridley Scott, 1982) (268), A Star Is Born (dir. William A. Wellman, 1937) (346), Our Hospitality (dir. Buster Keaton, 1923) (399), Labyrinth (dir. Jim Henson, 1986) (401), Legend (dir. Ridley Scott, 1985) (401), Howard the Duck (dir. Willard Huyck, 1986) (401), Dr Strangelove (dir. Stanley Kubrick, 1964) (402), Mephisto (dir. István Szabó, 1981) (416), The Battleship Potemkin (dir. Sergei Eisenstein, 1925) (439), Citizen Kane (dir. Orson Welles, 1941) (439), $81 / 2$ (dir. Federico Fellini, 1963) (439), The Seven Samurai (dir. Akira Kurosawa, 1954) (439), The Exterminating Angel (dir. Luis Buñuel, 1962) (439), and The Ten Commandments (dir. Cecil B. DeMille, 1956) (469); actors such as Peter Sellers (51), Mae West (60), Marilyn Monroe (61), Sigourney Weaver (62), Charlton Heston (132), Arnold Schwarzenegger (268), Rutger Hauer (268), Dustin Hoffman (341), Christopher Reeve (341), and Rex Harrison ("Rex-Harrisonian speech-song") (424) are referred to or playfully alluded to; and filmmakers Ridley Scott (62) and Orson Welles (266) are mentioned in passing. This list, despite its length, includes only a fraction of the references that dialogically constitute the cinematic intertexts of The Satanic Verses.

5. Supple also co-adapted Rushdie's 1990 novel Haroun and the Sea of Stories with dramaturg David Tushingham for the National Theatre (Cottesloe), where it premiered in October 1998 under heavy security measures (Supple and Tushingham, 1998).

6. References to the respective texts will be given parenthetically, marked as $M C$ (novel), $M C S$ (TV), $M C T$ (theatre), and $M C F$ (film).

7. The screenplay has not (yet) been published, so we are drawing here from our own notes on the film.

8. In this respect, Jenni Ramone (2013) adopts an expanded understanding of "translation", inasmuch as it can be used almost interchangeably with "adaptation". As for translation proper, we plan to analyse elsewhere the translation of equivalent passages into Portuguese and Finnish. Unlike the three adaptations, these translations have not been "author(iz)ed" by Rushdie. What we would like to examine is if they display additional (in the sense of different or contrastive) elements of audience adaptation.

9. The discussion goes well beyond the literary-cinematic pair, but these implications will not be considered here. See, for example, Constandinides (2010) and Brillenburg Wurth (2012).

10. However, in his reflections on the theatre adaptation, Rushdie himself makes the familial connection: "I thought of the play as a sort of second cousin of the book - perhaps its illegitimate child; its relative, not its mirror-image" (Rushdie, 2009).

11. An illustrative example of the derivative understanding of literature-to-film adaptations is the popular truism: "Read a good book before Hollywood ruins it".

12. See, for example: Carroll (2009); Cattrysse (1992); Connor (2007); Elliott (2004); Fischer (2013); Hutcheon (2006); McFarlane (1996); Nicklas and Lindner (2012); Ponzanesi (2011); Slethaug (2014); Stam (2005).

13. Cloud Atlas, novel by David Mitchell (2004); Silver Linings Playbook, novel by Matthew Quick (2008); Beasts of the Southern Wild, film adapted from the play "Juicy and Delicious" by Lucy Alibar (2010); and Life of Pi, novel by Yann Martel (2001).

14. Lucy Fischer (2013) lists the following works as her sources: Phebe Davidson (1997); Timothy Corrigan (2012/1999); James Naremore (2000); and Kamilla Elliott (2003). Besides these, Ella Shohat (2006: 82) discusses “theologies of adaptation”, making a direct reference to Rushdie and The Satanic Verses.

15. Although beyond the scope of this paper, tracing the history of the Academy Award for Best Adapted Screenplay would give us an idea of the extent to which literature has served as a constant inspiration for the entertainment industry of cinema.

16. He has also been reported as working on a sci-fi TV series The Next People for Showtime (Thorpe, 2011). 
17. See Midnight's Children Official Movie Trailer: Canada: https://youtu.be/IXgx6C8PHd4; UK: http://www.theguardian.com/culture/video/2012/dec/07/midnights-children-watch-thetrailer-video; US: https://youtu.be/3z6F5YMAhSc (accessed 12 September 2016).

18. An analysis of the ways in which the different trailers instrumentalize these perceptions to sell the film unfortunately falls outside the scope of this article.

19. With about 1.5 million viewers, the series dropped out of the Top Ten programmes by May 2015. Channel 4 decided to axe the series after failing ratings.

20. See Oliete Aldea (2009), especially Chapter 4.

21. For more details, see Kuortti (2012: 8).

22. The BBC originally hired screenwriter Ken Taylor to write the screenplay.

23. Norbert Schurer (2004: 12) notes that many aspects of Rushdie's biography were integrated into Midnight's Children. In The Satanic Verses, the appearance of a Rushdiesque authorcharacter created a lot of debate over the authorship issue in and around the novel. While there is no analogous character in Midnight's Children, the autobiographical readings have not been rare. In the Introduction to the 25th anniversary edition of the novel, Rushdie outlines some of these elements (Rushdie, 2006: ix-xii).

\section{References}

Ahmed I (2013) Review - Midnight's Children. Impact: The University of Nottingham's Official Student Magazine, 8 January. Available at: http://www.impactnottingham.com/2013/01/ review-midnights-children/ (accessed 11 September 2016).

Batty NE (1987) The art of suspense: Rushdie's 1001 (mid-)nights. Ariel 18(3): 49-65.

Billington M (2003) Midnight's Children. The Guardian, 30 January. Available at: http://www. theguardian.com/stage/2003/jan/30/theatre.artsfeatures3 (accessed 11 September 2016).

Bingham J (2011) TV drama is the new literature, says Salman Rushdie. The Telegraph, 12 June. Available at: http://www.telegraph.co.uk/culture/books/booknews/8571010/TV-drama-isthe-newliterature-says-Salman-Rushdie.html (accessed 11 September 2016).

Bluestone G (1957) Novels into Film. Baltimore: Johns Hopkins Press.

Boozer J (2008) Introduction: The screenplay and authorship in adaptation. In: Boozer J (ed.) Authorship in Film Adaptation. Austin: University of Texas Press, 1-30.

Bowen D (1990) Mimesis, magic, manipulation: A study of the photograph in contemporary British and Canadian novels. PhD Dissertation, University of Ottawa, Canada.

Brillenburg Wurth K (2012) Introduction. In: Brillenburg Wurth K (ed.) Between Page and Screen: Remaking Literature through Cinema and Cyberspace. New York: Fordham University Press, $1-23$.

Broadcasters' Audience Research Board (2015) Weekly top 10 programmes: Channel 4, February, Week 09 Feb-15 Feb. Available at: http://www.barb.co.uk/viewing-data/weekly-top-10/ (accessed 11 September 2016).

Canfield K (2013) Salman Rushdie and Deepa Mehta on Midnight's Children. Filmmaker, 17 April. Available at: http://filmmakermagazine.com/68782-salman-rushdie-and-deepa-mehtaon-midnights-children (accessed 11 September 2016).

Carroll R (ed.) (2009) Adaptation in Contemporary Culture: Textual Infidelities. London: Continuum.

Cattrysse P (1992) Film (adaptation) as translation: Some methodological proposals. Target 4(1): 53-70.

Connor JD (2007) The persistence of fidelity: Adaptation theory today. M/C Journal 10(2). Available at: http://journal.media-culture.org.au/0705/15-connor.php (accessed 11 September 2016). 
Constandinides C (2010) From Film Adaptation to Post-celluloid Adaptation: Rethinking the Transition of Popular Narratives and Characters across Old and New Media. New York: Continuum.

Corrigan T (2012/1999) Film and Literature: An Introduction and Reader (2nd ed.). Abingdon and New York: Routledge.

Cox S (2013) Midnight's Children - a very collaborative affair: Salman Rushdie (Interview). Midday, 22 April. Available at: http://www.mid-day.com/articles/midnights-children-a-verycollaborative-affair-salman-rushdie/209989 (accessed 11 September 2016).

Davidson P (ed.) (1997) Film and Literature: Points of Intersection. Lewiston: Edwin Mellen Press.

Elliott KL (2003) Rethinking the Novel/Film Debate. Cambridge: Cambridge University Press.

Elliott KL (2004) Literary film adaptation and the form/content dilemma. In Ryan M-L (ed.) Narrative across Media: The Languages of Storytelling. Lincoln: University of Nebraska Press, 220-246.

Fischer L (2013) Body Double: The Author Incarnate in the Cinema. New Brunswick: Rutgers University Press.

Fisher P (2003) Midnight's Children. British Theatre Guide. Available at: http://www.britishtheatreguide.info/reviews/midnightschildren-rev (accessed 11 September 2016).

Garfinkel P (2009) Beyond the screen. Wall Street Journal, 2 October. Available at: http://www. wsj.com/articles/SB125437693963755353 (accessed 11 September 2016).

Gilroy P (2004) Postcolonial Melancholia. New York: Columbia University Press.

Hutcheon L (2006) A Theory of Adaptation. New York: Routledge.

IBNLive (2011) I'm not doing Midnight's Children: Nandita Das. IBNLive, 24 February. Available at: http://www.ibnlive.com/news/india/im-not-doing-midnights-children-nanditadas-361526.html (accessed 11 September 2016).

Joshi P (2012) Midnight's Children review: A charming historical epic. Digital Spy, 24 December. Available at: http://www.digitalspy.co.uk/movies/review/a447149/midnights-childrenreview-a-charming-historical-epic.html (accessed 11 September 2016).

Kuortti J (2012) Midnight's Children: More useful than the facts. In Kuortti J (ed.) Critical Insights: Midnight's Children. Ipswich: Salem Press, 3-19.

Leitch T (2007) Film Adaptation and Its Discontents: From Gone with the Wind to The Passion of the Christ. Baltimore: Johns Hopkins University Press.

Leitch T (2008) Adaptation studies at a crossroads. Adaptation 1(1): 63-77.

McFarlane B (1996) Novel to Film: An Introduction to the Theory of Adaptation. Oxford: Clarendon Press.

Mehta D (dir.) (2012) Midnight's Children (DVD). Canada: David Hamilton Productions.

Mendes AC (ed.) (2012) Salman Rushdie and Visual Culture: Celebrating Impurity, Disrupting Borders. London: Routledge.

Mendes AC (2013) Salman Rushdie in the Cultural Marketplace. Farnham and Burlington, VT: Ashgate.

Mishra V (2012) Salman Rushdie, aesthetics and Bollywood popular culture. Thesis Eleven 113(1): 112-128.

Naremore J (ed.) (2000) Film Adaptation. New Brunswick: Rutgers University Press.

Natarajan N (1999/1994) Woman, nation and narration in Midnight's Children. In Price J and Shildrick M (eds) Feminist Theory and the Body: A Reader. London: Routledge, 398-409.

Nicklas P and Lindner O (eds) (2012) Adaptation and Cultural Appropriation: Literature, Film, and the Arts. Berlin: De Gruyter. 
Oliete Aldea E (2009) Filmic representations of the British Raj in the 1980s: Cultural identity, otherness and hybridity. PhD Dissertation, University of Zaragoza, Spain. Available at: https:// zaguan.unizar.es/record/3260/files/TESIS-2009-057.pdf (accessed 11 September 2016).

Parameswaran U (1983) Handcuffed to history: Salman Rushdie's art. Ariel 14(4): 34-45.

Phillips KJ (1989) Salman Rushdie's Midnight's Children: Models for storytelling, East and West. In: Moore CN and Moody RA (eds) Comparative Literature - East and West: Traditions and Trends. Honolulu: University of Hawaii Press, 202-207.

Ponzanesi S (2011) Postcolonial adaptations: Gained and lost in translation. In: Ponzanesi S and Waller M (eds) Postcolonial Cinema Studies. London: Routledge, 172-188.

Ramone J (2013) Salman Rushdie and Translation. London and New York: Bloomsbury.

Rombes ND (1993) The Satanic Verses as a cinematic narrative. Literature-Film Quarterly 21(1): 47-53.

Rushdie S (1981) Midnight's Children. London: Jonathan Cape.

Rushdie S (1982) The empire writes back with a vengeance. The Times, 3 July, 8.

Rushdie S (1983) Shame. London: Jonathan Cape.

Rushdie S (1984a) "Errata", or unreliable narration in Midnight's Children. In: Olinder B (ed.) A Sense of Place: Essays in Post-Colonial Literatures. Goteborg: Gothenburg University Commonwealth Studies, 98-100.

Rushdie S (1984b) Outside the whale. Granta 11. Available at: http://granta.com/outside-thewhale/ (accessed 11 September 2016).

Rushdie S (1989/1988) The Satanic Verses. New York: Viking.

Rushdie S (1990) Haroun and the Sea of Stories. London: Granta in association with Penguin.

Rushdie S (1991) In good faith. In: Imaginary Homelands: Essays and Criticism 1981-1991. London: Granta in association with Penguin, 393-414.

Rushdie S (1999a) Introduction. In: The Screenplay of Midnight's Children. London: Vintage, $1-12$.

Rushdie S (1999b) The Screenplay of Midnight's Children. London: Vintage.

Rushdie S (2002) Step Across This Line: Collected Nonfiction 1992-2002. New York: Random House.

Rushdie S (2006) Introduction to the 25th anniversary edition. In: Midnight's Children (25th anniversary edition). New York: Random House: ix-xvi.

Rushdie S (2009) A fine pickle. The Guardian, 28 February. Available at: http://www.theguardian.com/books/2009/feb/28/salman-rushdie-novels-film-adaptations (accessed 11 September 2016).

Rushdie S (2012) Joseph Anton: A Memoir. New York: Random House.

Rushdie S, Reade S and Supple T (2002) Salman Rushdie's Midnight's Children: Adapted for the Theatre. London: Vintage.

Shohat E (2006) Sacred word, profane image: Theologies of adaptation. In: Taboo Memories, Diasporic Voices. Durham: Duke University Press, 70-105.

Schurer N (2004) Salman Rushdie's Midnight's Children: A Reader's Guide. New York and London: Continuum.

Slethaug GE (2014) Adaptation Theory and Criticism: Postmodern Literature and Cinema in the US. London: Bloomsbury.

Stadtler F (2013) Fiction, Film and Indian Popular Cinema: Salman Rushdie's Novels and the Cinematic Imagination. New York: Routledge.

Stam R (2005) Introduction: The theory and practice of adaptation. In: Stam R and Raengo A (eds) Literature and Film: A Guide to the Theory and Practice of Adaptation. New York: Blackwell, 1-52. 
Stam R (2012-13) Adaptation and the French New Wave: A study in ambivalence. Interfaces 34: 177-197.

Stephens J (1985) “To tell the truth, I lied...”: Retrospectivity and deconstruction as (contributing) strategies for reading Salman Rushdie's Midnight's Children. SPAN 21: 193-208.

Sterne L (2009/1759-67) The Life and Opinions of Tristram Shandy, Gentleman. Oxford: Oxford University Press.

Supple T and Tushingham D (1998) Salman Rushdie's Haroun and the Sea of Stories (Adaptation). London: Faber.

“Theatre" (2015) Encyclopcedia Britannica. Available at: http://global.britannica.com/EBchecked/ topic/590239/theatre/39384/India (accessed 11 September 2016).

Thorpe V (2011) Salman Rushdie says TV dramas comparable to novels. The Guardian, 12 June. Available at: http://www.theguardian.com/books/2011/jun/12/salman-rushdie-write-tvdrama (accessed 11 September 2016).

Valovirta E and Kuortti J (forthcoming) Losing one's illusions: Affective sense-making in Salman Rushdie's Joseph Anton and the popular media.

Varadpande ML (1992) History of Indian Theatre, Vol. 2: Loka Ranga, Panorama of Indian Folk Theatre. New Delhi: Abhinav Publications.

Wallace-Wells D (2013) Salman Rushdie turns screenwriter for Midnight's Children. Vulture, 21 April. Available at: http://www.vulture.com/2013/04/salman-rushdie-turns-screenwriter-formidnights-children.html (accessed 11 September 2016). 